\title{
Quantification of long-term precipitation use efficiencies of different maize production practices on a semi-arid ecotope in the Free State Province
}

\author{
TB Zere, CW van Huyssteen* and M Hensley \\ Department of Soil, Crop and Climate Sciences, University of the Free State, PO Box 339, Bloemfontein 9300, South Africa
}

\begin{abstract}
Precipitation use efficiency (PUE) was estimated for four production practices, i.e. conventional tillage with November planting (CTN), conventional tillage with January planting (CTJ), in-field rainwater harvesting with November planting (WHBN), and in-field rainwater harvesting with January planting (WHBJ), over 80 maize seasons for a semi-arid ecotope in the central Free State Province of South Africa. An empirical yield prediction model was used to obtain maize grain yields. PUE was expressed as the ratio of transpiration: rainfall for each growing season $\left(\mathrm{PUE}_{\mathrm{T}}\right)$, while transpiration was calculated from total biomass yield, vapour pressure deficit and a transpiration efficiency coefficient for maize. The following equation, based on 10 years of measured data, was developed to estimate daily vapour deficit pressure for the 80 seasons from daily maximum temperature: $\mathrm{Vd}=0.163 \times \mathrm{T}_{\max }-2.88\left(\mathrm{R}^{2}=0.73\right)$. Mean $\mathrm{PUE}_{\mathrm{T}}$ values over the 80 seasons were: 0.260 for $\mathrm{CTN}, 0.320$ for WHBN, 0.334 for CTJ, and 0.400 for WHBJ. These results confirmed and quantified the advantage of in-field rainwater harvesting over conventional tillage, and the advantage of January planting over November planting. $\mathrm{PUE}_{\mathrm{T}}$ results were also expressed as cumulative probability functions. Significance tests showed that PUE $_{\mathrm{T}}$ for in-field rainwater harvesting was significantly better than PUE $_{\mathrm{T}}$ for conventional tillage, and that January planting was significantly better than November planting. It was concluded that the advantage of in-field rainwater harvesting over conventional tillage was mainly due to the absence of runoff and reduced evaporation in the former practice. The use of a short-growing cultivar, which flowers during the month with the most favourable climate, i.e. March, probably resulted in the advantage of January planting over November planting.
\end{abstract}

Keywords: conventional tillage, in-field rain water harvesting, planting date, transpiration, vapour pressure deficit

\section{Introduction}

Water availability is the most important limiting factor for rainfed crop production in semi-arid areas. Maximising precipitation use efficiency (PUE) is therefore important. This can be achieved by identifying and employing the crop production practice with the highest PUE for that specific ecotope. The ecotope concept is defined by MacVicar et al. (1974).

Water use efficiency (WUE) has been widely used in the past to calculate crop water use efficiency (Hillel, 1972; Tanner and Sinclair, 1983):

$$
\mathrm{WUE}=\frac{\mathrm{Y}}{\mathrm{E}+\mathrm{T}} \mathrm{kg} \cdot \mathrm{ha}^{-1} \cdot \mathrm{mm}^{-1}
$$

where:

$\mathrm{Y}=$ grain yield $\left(\mathrm{kg} \cdot \mathrm{ha}^{-1}\right)$

$\mathrm{E}=$ water lost from the soil surface through evaporation during the growing season ( $\mathrm{mm}$ )

$\mathrm{T}=$ water used for transpiration during the growing season $(\mathrm{mm})$

WUE is a measure of the efficiency with which a crop uses water to produce a certain yield. Although valuable in certain cases, WUE does not enable the comparison of different production practices. This is because certain water loss processes, which

\footnotetext{
* To whom all correspondence should be addressed.

용 +2751 401 9247; fax: +2751 4012212 ;

e-mail: vhuystc.sci@mail.uovs.ac.za

Received31 May 2006; accepted in revised form 16 November 2006.
}

can be minimised by using suitable water conservation tillage (WCT) practices to improve the efficiency of rainwater use in crop production, are not taken into account. These losses include runoff, evaporation and deep drainage, during the growing and fallow seasons. Precipitation use efficiency $\left(\mathrm{PUE}_{\mathrm{Y}}\right)$ is considered to be a more appropriate parameter to describe the overall efficiency with which rainwater is used in rain-fed cropping, since the named losses are taken into account (Hensley et al., 1990):

$$
\mathrm{PUE}_{\mathrm{Y}}=\frac{\mathrm{Y}}{\mathrm{P}_{\mathrm{g}}+\mathrm{P}_{\mathrm{f}}+\left(\theta_{\mathrm{h}(\mathrm{n}-1)}-\theta_{\mathrm{h}(\mathrm{n})}\right)} \mathrm{kg} \cdot \mathrm{ha}^{-1} \cdot \mathrm{mm}^{-1}
$$

where:

$\mathrm{PUE}_{\mathrm{Y}}=$ precipitation use efficiency for a particular year, including the fallow season, based on the grain yield $\left(\mathrm{kg} \cdot \mathrm{ha}^{-1} \cdot \mathrm{mm}^{-1}\right)$

$\mathrm{Y} \quad=$ grain yield $\left(\mathrm{kg} \cdot \mathrm{ha}^{-1}\right)$

$\mathrm{P}_{\mathrm{g}} \quad=$ precipitation during the growing season $(\mathrm{mm})$

$\mathrm{P}_{\mathrm{f}}^{\mathrm{g}} \quad=$ precipitation during the fallow season $(\mathrm{mm})$

$\theta_{\mathrm{h}(\mathrm{n})}=$ water content of the root zone at harvest in year $\mathrm{n}(\mathrm{mm})$

$\theta_{\mathrm{h}(\mathrm{n}-1)}=$ water content of the root zone at harvest in year $\mathrm{n}-1(\mathrm{~mm})$

$\mathrm{PUE}_{\mathrm{Y}}$ is therefore the grain yield per unit of total rainfall associated with a particular crop, during a particular year. It is necessary to include $\mathrm{P}_{\mathrm{f}}$ in Eq. (2) because certain WCT practices result in improved water conservation during the fallow season as well as during the growing season. Such practices generally result in more plant available water at the start of the following growing season than where WCT practices had not been applied 
during the fallow season. During the growing season unproductive water losses, such as runoff, deep drainage, and excessive evaporation from the soil, will be less on WCT land, resulting in more water being available for growth and therefore increased yield and increased $\mathrm{PUE}_{\mathrm{Y}}$. $\mathrm{PUE}_{\mathrm{Y}}$ therefore enables a meaningful and comprehensive comparison to be made between the efficiencies of different production practices.

However, $\mathrm{PUE}_{\mathrm{Y}}$ is not strictly an 'efficiency' term. Gregory (1989) stated that 'the two processes (plant growth and water use) are not energetically linked so that a theoretical, maximum value cannot be calculated'. The ratio of transpiration ( $T$, in $\mathrm{mm})$ to the total available rainfall $(\mathrm{mm})$ would therefore provide a better assessment of efficiency (Eq. (3)).

$$
\mathrm{PUE}_{\mathrm{T}}=\frac{\mathrm{T}}{\mathrm{P}_{\mathrm{g}}+\mathrm{P}_{\mathrm{f}}+\left(\theta_{\mathrm{h}(\mathrm{n}-1)}-\theta_{\mathrm{h}(\mathrm{n})}\right)} \mathrm{mm} \cdot \mathrm{mm}^{-1}
$$

Equation (3) can be used for making comparisons between $\mathrm{PUE}_{\mathrm{T}}$ values for different seasons for particular, or different, production practices. For long-term comparisons the term $\left(\theta_{\mathrm{h}(\mathrm{n}-1)}\right.$ $\left.-\theta_{\mathrm{h(n)}}\right)$, however, loses its meaning. Any benefit (positive value) or loss (negative value) which the term may have will be conveyed to the following season. The term $\left(\theta_{\mathrm{h}(\mathrm{n}-1)}-\theta_{\mathrm{h}(\mathrm{n})}\right)$ is also generally expected to be very small relative to $\left(\mathrm{P}_{\mathrm{g}}+\mathrm{P}_{\mathrm{f}}\right)$. Firstly, it describes the water content at the end of the growing season - almost invariably a very low value in semi-arid areas; and secondly, it describes the difference between two such values during consecutive seasons. The influence of the term $\left(\theta_{\mathrm{h}(\mathrm{n}-1)}\right.$ $\left.-\theta_{\mathrm{h}(\mathrm{n})}\right)$ on $\mathrm{PUE}_{\mathrm{T}}$ for different production practices during different seasons is also very variable. Compare, for example, the influence of conventional tillage (CT) and WCT on this term for a particular growing season with a specific rainfall distribution pattern. Where the rainfall is high at the end of the previous growing season (high $\theta_{\mathrm{h}(\mathrm{n}-1)}$ ), and low at the end of the current growing season (low $\left(\theta_{\mathrm{h}(\mathrm{n})}\right)$, the term will be positive and larger for a WCT treatment (Fig. 1) than for a CT treatment. This will promote $\mathrm{PUE}_{\mathrm{T}}(\mathrm{WCT})$ relative to $\mathrm{PUE}_{\mathrm{T}}(\mathrm{CT})$, for that particular season. The yield, and therefore the T value, of the WCT treatment will have benefited by having higher plant-available water at planting than the CT treatment for the particular season for which the calculation is being made. A wide range of different scenarios can be considered in this way, with the WCT treatment benefiting on overall because water losses are minimised. This is confirmed by the results of field experiments reported by
Botha (2006). Equation (4) would therefore be acceptable for long-term comparisons of $\mathrm{PUE}_{\mathrm{T}}$ for different production practices:

$$
\mathrm{PUE}_{\mathrm{T}}=\frac{\mathrm{T}}{\mathrm{P}_{\mathrm{g}}+\mathrm{P}_{\mathrm{f}}} \mathrm{mm} \cdot \mathrm{mm}^{-1}
$$

$\mathrm{PUE}_{\mathrm{T}}$ is dimensionless as both the numerator and denominator are in $\mathrm{mm}$. The theoretical minimum and maximum will therefore be 0 and 1 respectively. The comment of Gregory (1989) regarding the requirements of a true efficiency term is therefore met by Eq. (4).

The purpose of this paper was to quantify and compare the precipitation use efficiencies of four crop production practices on a semi-arid ecotope at Glen.

\section{Material and methods}

The Glen/Hutton-Ventersdorp ecotope is located at Glen $\left(28^{\circ}\right.$ 55.691' S, $26^{\circ} 19.599^{\prime} \mathrm{E}$ ), in the central, semi-arid area of the Free State Province of South Africa. The mean annual rainfall is $545 \mathrm{~mm}$ and potential evaporation (Class A pan) is 2243 $\mathrm{mm}$, giving an average aridity index (rainfall/potential evaporation) of 0.23 per year, and 0.32 for the November to April growing season (Botha et al., 2003). The ecotope occurs on a mid-slope terrain morphological unit, with a $3 \%$ westerly slope. The soil was classified as a $1800 \mathrm{~mm}$ deep HuttonVentersdorp sandy loam (Soil Classification Working Group, 1991). A detailed soil profile description and soil analyses are given by Zere (2003).

Four production practices, based on combinations of the following were used: Conventional tillage (CT), consisting of mouldboard ploughing followed by offset-disc land preparation for planting. Weed control was done by cultivation. The in-field rainwater harvesting with basins (WHB) technique is described in Fig. 1. It results in water being conserved in the following ways during the fallow and growing seasons: ex-field rainwater runoff is prevented; evaporation from the soil surface (Es) is reduced by the presence of mulch in the basins; and Es is suppressed by promoting deep infiltration of the runoff water in the basin area. Weed control was done chemically. November $(\mathrm{N})$ or early planting utilised a long growing season (145 d) maize cultivar, while January $(\mathrm{J})$ planting utilised a short growing season $(120 \mathrm{~d})$ maize cultivar. The production practices were categorised as follows:

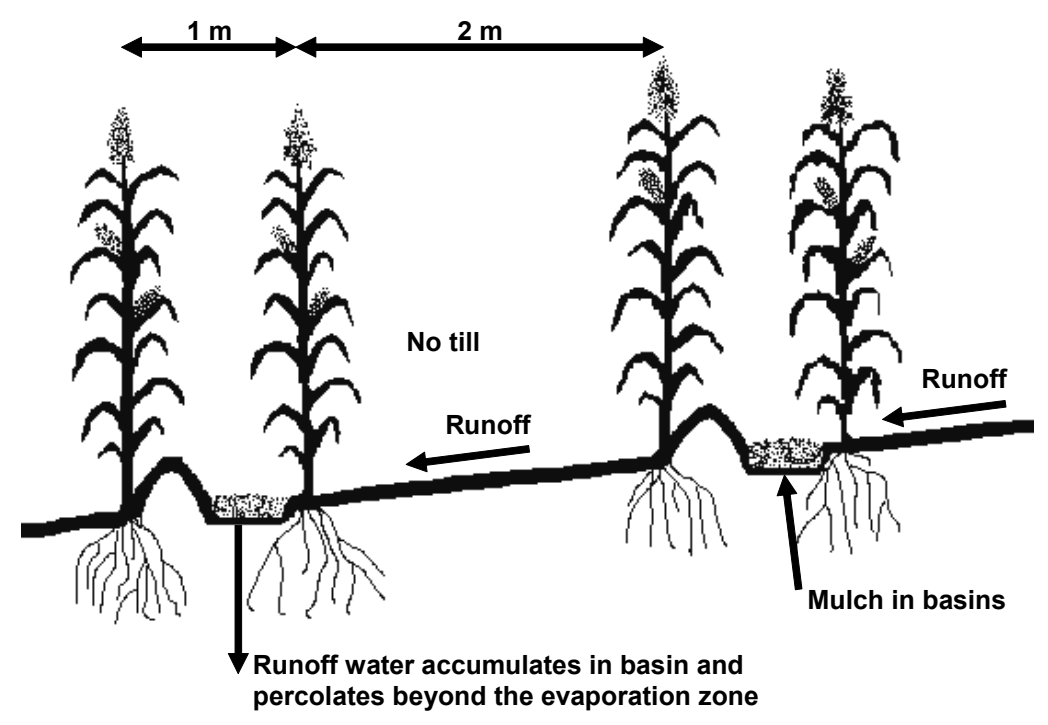

Figure 1

A diagrammatic description of the in-field rain water harvesting production technique (After Hensley et al, 2000) 
(i) November planting with conventional tillage (CTN)

(ii) November planting with in-field rainwater harvesting (WHBN)

(iii) January planting with conventional tillage (CTJ)

(iv) January planting with in-field rainwater harvesting (WHBJ)

Biomass yields for maize $\left(\mathrm{Y}_{\mathrm{b}}\right)$ for each of these production practices for the seasons $1922 / 23$ to $2001 / 02$, were estimated using a yield prediction procedure, developed for these ecotopes, based on the evapotranspiration (ET) to potential evaporation (Eo) ratio, and validated against measured maize grain yields for 22 seasons, (Zere et al., 2005a). Total biomass $\left(\mathrm{Y}_{\mathrm{b}}\right)$ was estimated by multiplying the above ground biomass yields with a factor of 1.2 (Tanner and Sinclair, 1983).

The $\mathrm{PUE}_{\mathrm{T}}$ for each growing season was calculated using Eq. (4). Because measured $T$ was not available, it was calculated from the total biomass yield $\left(\mathrm{Y}_{\mathrm{b}}\right)$, vapour pressure deficit $(\mathrm{Vd})$, and the transpiration efficiency coefficient $(\mathrm{k})$, based on the relationship proposed by Tanner and Sinclair (1983) and Gregory (1989):

$$
\mathrm{k}=\frac{\mathrm{Y}_{\mathrm{bt}} \times \mathrm{Vd}}{\mathrm{T}} \mathrm{kg} \cdot \mathrm{ha}^{-1} \cdot \mathrm{kPa} \cdot \mathrm{mm}^{-1}
$$

where:

$$
\begin{aligned}
\mathrm{k}= & \begin{array}{l}
\text { transpiration efficiency coefficient for maize } \\
\left(\mathrm{kg} \cdot \mathrm{ha}^{-1} \cdot \mathrm{kPa} \cdot \mathrm{mm}^{-1}\right)
\end{array} \\
\mathrm{Y}_{\mathrm{bt}}= & \text { total biomass yield }\left(\mathrm{kg} \cdot \mathrm{ha}^{-1}\right) \\
\mathrm{Vd}= & \begin{array}{l}
\text { average vapour pressure deficit }(\mathrm{kPa}) \text { during } \\
\text { sunlight hours, over the growing season }
\end{array} \\
\mathrm{T}= & \text { transpiration }(\mathrm{mm})
\end{aligned}
$$

The units of $\mathrm{Y}_{\mathrm{bt}}$ can be simplified by dividing by 10 to give $\mathrm{g} \cdot \mathrm{m}^{-2}$. To further simplify the units of k, Gregory (1989) proposed 'normalising' Vd by dividing by $\mathrm{Vd}_{\mathrm{o}}(1 \mathrm{kPa})$. Following this procedure the units of $\mathrm{k}$ become $\mathrm{g} \cdot \mathrm{m}^{-2} \cdot \mathrm{mm}^{-1}$. Tanner and Sinclair (1983) reported a $\mathrm{k}$ value of $9.5 \mathrm{~g} \cdot \mathrm{m}^{-2} \cdot \mathrm{mm}^{-1}$ for maize. Similar values for maize were reported by Walker (1986) working in Canada and Hattingh (1993) working at Glen, when the appropriate conversion for the above-ground biomass to total biomass had been made (Hensley et al., 2000). The value of 9.5 $\mathrm{g} \cdot \mathrm{m}^{-2} \cdot \mathrm{mm}^{-1}$ has therefore been considered acceptable for this study. Changing the subject in Eq. (5) enables the calculation of T:

$$
\mathrm{T}=\frac{\mathrm{Y}_{\mathrm{bt}} \times \mathrm{Vd}}{\mathrm{k}} \mathrm{mm}
$$

where:

$\mathrm{Vd}=$ as in Eq. (5), but considered to be unit-less due to division by $1 \mathrm{kPa}$

A problem which arose was that measured Vd values were not available for each of the 80 growing seasons (1922/23 to 2001/02) for which $Y_{b t}$ values could be estimated. The following procedure was followed to obtain acceptable estimates of $\mathrm{Vd}$ values for the study period. There is a fixed relationship between the saturated vapour pressure of the atmosphere (Vs) and the temperature (Allen et al., 1998):

$$
V s=0.6108 \times e^{\left(\frac{17.27 \times T_{a v}}{T_{a v}+273.2}\right)}
$$

where:

$$
\begin{aligned}
\mathrm{Vs}= & \text { average hourly saturation vapour pressure of the } \\
& \text { atmosphere }(\mathrm{kPa}) \\
\mathrm{T}_{\mathrm{av}}= & \text { average hourly temperature }\left({ }^{\circ} \mathrm{C}\right)
\end{aligned}
$$

and:

$$
\mathrm{Vd}=\mathrm{Vs}-\mathrm{Va}
$$

and:

$$
\mathrm{Va}=\frac{\mathrm{Vs} \times \mathrm{RH}}{100}
$$

where:

$\mathrm{Va}=$ actual vapour pressure $(\mathrm{kPa})$

$\mathrm{RH}=$ relative humidity $(\%)$

therefore:

$$
\mathrm{Vd}=\mathrm{Vs}-\left(\mathrm{Vs} \times \frac{\mathrm{RH}}{100}\right)
$$

Since Vs is directly related to $\mathrm{T}_{\text {av }}$ (Eq. (7)), and RH is also related

\begin{tabular}{|c|c|c|c|c|}
\hline $\begin{array}{l}\text { Sun } \\
\text { the } c\end{array}$ & $\begin{array}{l}\text { hine per } \\
\text { culation } \\
\text { eficit (V) }\end{array}$ & $\begin{array}{l}\text { TABLE } \\
\text { ds for B } \\
\text { f mean } \\
\text { for all } g\end{array}$ & $\begin{array}{l}1 \\
\text { pemfontein } \\
\text { aily vapour } \\
\text { owing seas }\end{array}$ & $\begin{array}{l}\text { used in } \\
\text { pressure } \\
\text { ons }\end{array}$ \\
\hline Month & & shine pe & $\operatorname{iod}^{1}$ & Sunshine \\
\hline & Sunrise & Sunset & $\begin{array}{l}\text { Day length } \\
\text { (hours) }\end{array}$ & \\
\hline Dec & 05:00 & $19: 00$ & $14: 00$ & 13.9 \\
\hline Jan & 05:00 & $19: 00$ & $14: 00$ & 13.7 \\
\hline Feb & 06:00 & $19: 00$ & $13: 00$ & 13.0 \\
\hline Mar & 06:00 & 18:00 & $12: 00$ & 12.2 \\
\hline Apr & $07: 00$ & $18: 00$ & $11: 00$ & 11.3 \\
\hline
\end{tabular}
to temperature, it is logical to expect some degree of correlation between $\mathrm{Vd}$ and temperature. The following procedure was adopted to identify the best relationship between temperature and Vd.

Hourly Vd values were available for the nearby Bloemfontein airport meteorological station $\left(29^{\circ} 10^{\prime} \mathrm{S} ; 26^{\circ} 30^{\prime} \mathrm{E}\right)$ for the period 01/01/1992 to 31/04/2002 (SAWS, 2005). Hourly Vd data were averaged over the sunshine hours to obtain Vd values for each day over the growing season (December to April) for 10 years, giving 1635 data points. The sunshine hours at Bloemfontein for each day over the growing season (Table 1) are available from Allen et al. (1998) and from SAWS (2005). Day length in full hours was used in calculations, because only hourly data were available.

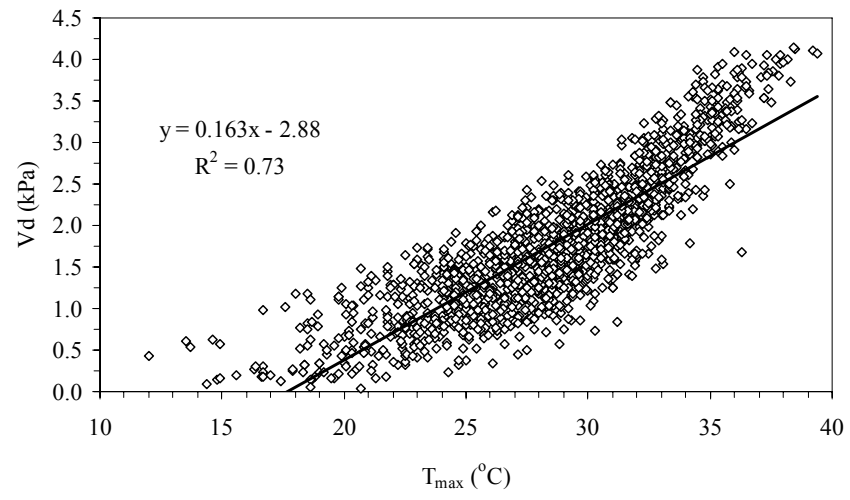

Figure 2

Regression of daily vapour pressure deficit ( $V d)$ against daily maximum temperature $\left(T_{\text {m }}\right)$, during the growing season, for the Bloemfontein meteorological station over ten years $(n=1635)$ 


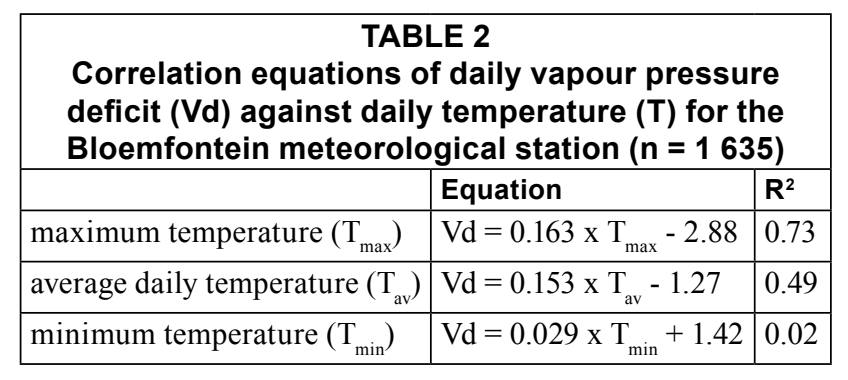

\begin{tabular}{|c|c|c|c|c|c|c|c|c|c|}
\hline \multicolumn{10}{|c|}{$\begin{array}{l}\text { TABLE } 3 \\
\text { Long-term precipitation use efficiency }\left(\mathrm{PUE}_{\mathrm{T}}\right) \text { for the Glen/Hutton-Ventersdorp ecotope } \\
\text { using November planting with conventional tillage (CTN), November planting with in-field } \\
\text { rainwater harvesting (WHBN), January planting with conventional tillage (CTJ), and Janu- } \\
\text { ary planting with in-field rainwater harvesting (WHBJ) }\end{array}$} \\
\hline \multirow{2}{*}{$\begin{array}{l}\text { Growing } \\
\text { season }\end{array}$} & \multicolumn{4}{|c|}{ Production technique } & \multirow{2}{*}{$\begin{array}{l}\text { Growing } \\
\text { Season }\end{array}$} & \multicolumn{4}{|c|}{ Production technique } \\
\hline & CTN & WHBN & CTJ & WHBJ & & CTN & WHBN & CTJ & WHBJ \\
\hline $1922 / 23$ & 0.284 & 0.414 & 0.205 & 0.262 & $62 / 63$ & 0.157 & 0.227 & 0.257 & 0.305 \\
\hline $23 / 24$ & 0.309 & 0.410 & 0.308 & 0.371 & $63 / 64$ & 0.186 & 0.278 & 0.537 & 0.624 \\
\hline $24 / 25$ & 0.159 & 0.205 & 0.322 & 0.415 & $64 / 65$ & 0.362 & 0.419 & 0.343 & 0.383 \\
\hline $25 / 26$ & 0.324 & 0.408 & 0.358 & 0.434 & $65 / 66$ & 0.319 & 0.415 & 0.111 & 0.256 \\
\hline $26 / 27$ & 0.339 & 0.424 & 0.317 & 0.471 & $66 / 67$ & 0.190 & 0.217 & 0.202 & 0.253 \\
\hline $27 / 28$ & 0.210 & 0.259 & 0.238 & 0.283 & $67 / 68$ & 0.363 & 0.323 & 0.325 & 0.401 \\
\hline $28 / 29$ & 0.247 & 0.290 & 0.357 & 0.432 & $68 / 69$ & 0.267 & 0.357 & 0.468 & 0.581 \\
\hline $29 / 30$ & 0.191 & 0.243 & 0.299 & 0.386 & $69 / 70$ & 0.498 & 0.521 & 0.329 & 0.526 \\
\hline $30 / 31$ & 0.169 & 0.215 & 0.208 & 0.274 & $70 / 71$ & 0.230 & 0.241 & 0.274 & 0.466 \\
\hline $31 / 32$ & 0.227 & 0.276 & 0.410 & 0.474 & $71 / 72$ & 0.234 & 0.301 & 0.246 & 0.320 \\
\hline $32 / 33$ & 0.299 & 0.351 & 0.527 & 0.626 & $72 / 73$ & 0.447 & 0.548 & 0.322 & 0.386 \\
\hline $33 / 34$ & 0.181 & 0.232 & 0.256 & 0.281 & $73 / 74$ & 0.223 & 0.231 & 0.191 & 0.214 \\
\hline $34 / 35$ & 0.208 & 0.262 & 0.310 & 0.374 & $74 / 75$ & 0.237 & 0.343 & 0.267 & 0.286 \\
\hline $35 / 36$ & 0.213 & 0.270 & 0.351 & 0.404 & $75 / 76$ & 0.179 & 0.232 & 0.221 & 0.260 \\
\hline $36 / 37$ & 0.213 & 0.285 & 0.292 & 0.358 & $76 / 77$ & 0.232 & 0.320 & 0.332 & 0.409 \\
\hline $37 / 38$ & 0.278 & 0.307 & 0.297 & 0.337 & $77 / 78$ & 0.269 & 0.343 & 0.259 & 0.310 \\
\hline $38 / 39$ & 0.228 & 0.263 & 0.251 & 0.279 & $78 / 79$ & 0.358 & 0.420 & 0.516 & 0.577 \\
\hline $39 / 40$ & 0.195 & 0.235 & 0.344 & 0.429 & $79 / 80$ & 0.347 & 0.393 & 0.417 & 0.442 \\
\hline $40 / 41$ & 0.281 & 0.362 & 0.236 & 0.275 & $80 / 81$ & 0.240 & 0.302 & 0.180 & 0.197 \\
\hline $41 / 42$ & 0.300 & 0.331 & 0.321 & 0.391 & $81 / 82$ & 0.184 & 0.237 & 0.320 & 0.422 \\
\hline $42 / 43$ & 0.188 & 0.233 & 0.274 & 0.316 & $82 / 83$ & 0.328 & 0.385 & 0.450 & 0.497 \\
\hline $43 / 44$ & 0.180 & 0.222 & 0.394 & 0.425 & $83 / 84$ & 0.204 & 0.417 & 0.521 & 0.589 \\
\hline $44 / 45$ & 0.276 & 0.343 & 0.328 & 0.408 & $84 / 85$ & 0.314 & 0.344 & 0.297 & 0.365 \\
\hline $45 / 46$ & 0.257 & 0.347 & 0.241 & 0.304 & $85 / 86$ & 0.271 & 0.340 & 0.312 & 0.388 \\
\hline $46 / 47$ & 0.257 & 0.320 & 0.350 & 0.421 & $86 / 87$ & 0.493 & 0.574 & 0.380 & 0.457 \\
\hline $47 / 48$ & 0.173 & 0.232 & 0.263 & 0.327 & $87 / 88$ & 0.187 & 0.196 & 0.211 & 0.245 \\
\hline $48 / 49$ & 0.446 & 0.453 & 0.423 & 0.449 & $88 / 89$ & 0.170 & 0.260 & 0.247 & 0.287 \\
\hline $49 / 50$ & 0.198 & 0.236 & 0.427 & 0.513 & $89 / 90$ & 0.287 & 0.293 & 0.303 & 0.366 \\
\hline $50 / 51$ & 0.164 & 0.205 & 0.413 & 0.470 & $90 / 91$ & 0.254 & 0.289 & 0.346 & 0.413 \\
\hline $51 / 52$ & 0.398 & 0.478 & 0.237 & 0.277 & $91 / 92$ & 0.616 & 0.640 & 0.892 & 0.926 \\
\hline $52 / 53$ & 0.183 & 0.230 & 0.225 & 0.353 & $92 / 93$ & 0.217 & 0.257 & 0.389 & 0.463 \\
\hline $53 / 54$ & 0.199 & 0.258 & 0.280 & 0.331 & $93 / 94$ & 0.292 & 0.385 & 0.242 & 0.268 \\
\hline $54 / 55$ & 0.342 & 0.369 & 0.458 & 0.506 & $94 / 95$ & 0.292 & 0.377 & 0.351 & 0.420 \\
\hline $55 / 56$ & 0.126 & 0.199 & 0.265 & 0.287 & $95 / 96$ & 0.271 & 0.343 & 0.382 & 0.486 \\
\hline $56 / 57$ & 0.300 & 0.273 & 0.378 & 0.406 & $96 / 97$ & 0.194 & 0.272 & 0.348 & 0.428 \\
\hline $57 / 58$ & 0.316 & 0.246 & 0.405 & 0.499 & $97 / 98$ & 0.253 & 0.394 & 0.274 & 0.376 \\
\hline $58 / 59$ & 0.151 & 0.326 & 0.298 & 0.350 & 98/99 & 0.274 & 0.322 & 0.547 & 0.592 \\
\hline $59 / 60$ & 0.158 & 0.251 & 0.310 & 0.441 & $99 / 00$ & 0.239 & 0.269 & 0.359 & 0.390 \\
\hline $60 / 61$ & 0.162 & 0.306 & 0.341 & 0.366 & $00 / 01$ & 0.239 & 0.291 & 0.386 & 0.458 \\
\hline \multirow[t]{2}{*}{$61 / 62$} & 0.220 & 0.318 & 0.339 & 0.413 & $01 / 02$ & 0.305 & 0.381 & 0.501 & 0.556 \\
\hline & & & & & Mean & 0.260 & 0.320 & 0.334 & 0.400 \\
\hline
\end{tabular}


Available temperature data for the 80 seasons comprised $\mathrm{T}_{\max }$ and $\mathrm{T}_{\min }$, from which $\mathrm{T}_{\mathrm{av}}$ could be calculated. Because $\mathrm{T}_{\max }$ will almost invariably occur during sunshine hours, it was expected that the best correlation will be between $\mathrm{Vd}$ and $\mathrm{T}_{\max }$. Correlations with $\mathrm{T}_{\mathrm{av}}$ and $\mathrm{T}_{\min }$ were nevertheless also tested against the 1635 data points. Results are presented in Table 2 . As predicted, $\mathrm{T}_{\max }$ had the best correlation $\left(\mathrm{R}^{2}=0.73\right)$ with $\mathrm{Vd}$ (Fig. 2). Equation (11) could therefore be used to estimate $\mathrm{Vd}$ from long-term $\mathrm{T}_{\max }$ data.

$$
\mathrm{Vd}=0.163 \times \mathrm{T}_{\max }-2.88 \mathrm{R}^{2}=0.73
$$

$\mathrm{PUE}_{\mathrm{T}}$ for each production practice could therefore be calculated using Eqs. (4), (6) and (11). The resulting $\mathrm{PUE}_{\mathrm{T}}$ data were expressed as cumulative probability functions, and average values. This gave 'treatments' (conventional tillage vs. in-field rainwater harvesting and November vs. January planting) that could be evaluated against each other, using the KolmogorovSmirnov test (Steel et al., 1997).

\section{Results and discussion}

PUE $_{\mathrm{T}}$ was calculated, using Eqs. (4), (6) and (11), for each of the four production practices over 80 seasons $(1922 / 23$ to $2001 / 02)$ on the Glen Hutton-Ventersdorp ecotope (Table 3).

November planting with conventional tillage (CTN) had the lowest mean $\mathrm{PUE}_{\mathrm{T}}=0.260$, followed by November planting with in-field rainwater harvesting $(\mathrm{WHBN})$, with mean $\mathrm{PUE}_{\mathrm{T}}=$ 0.320 , January planting with conventional tillage (CTJ), mean $\mathrm{PUE}_{\mathrm{T}}=0.334$ and January planting with in-field rainwater harvesting (WHBJ), mean $\mathrm{PUE}_{\mathrm{T}}=0.400$ (Table 3). The $\mathrm{PUE}_{\mathrm{T}}$ values for WHBJ are higher than those for CTJ for all the years, and values for WHBN are higher than CTN for 77 out of the 80 years (Table 3).

The cumulative probability functions for conventional tillage and in-field rainwater harvesting are plotted in Fig. 3. The clear separation between the two lines in Fig. 3, and the high significant difference (Table 4) confirmed and quantified the advantage of the in-field rainwater harvesting production practice over the conventional tillage production practice for almost all 80 seasons studied. The main advantage was probably due to the absence of runoff, and reduced evaporation in the in-field rainwater harvesting production practice, compared to the conventional tillage production practice with more evaporation and considerable runoff (Zere et al., 2005b). These $\mathrm{PUE}_{\mathrm{T}}$ results are similar to values obtained in field experiments on another ecotope at the Glen experiment station, where average $\mathrm{PUE}_{\mathrm{T}}$ values over four consecutive growing seasons for $\mathrm{CT}$ and WHB treatments on a Glen/Bonheim-Onrus ecotope were 0.145 and 0.250 respectively (Botha, 2006).

November and January planting could also be evaluated, using the available dataset (Fig. 4). January planting was significantly more efficient in terms of rainfall use than November planting (Table 4). Maize is very sensitive to drought conditions during flowering. Maize planted in November will flower in January which has a long-term average aridity index (AI) of 0.30 , whereas maize planted early in January will flower in March with an equivalent AI value of 0.46 (Botha et al., 2003). The advantage of January planting is therefore clearly due to a more favourable climate during flowering. January planting is only possible with a short-season cultivar as the heat units available become marginal in April and later.

Figure 5 shows the cumulative probability functions for the CTN, CTJ, WHBN and WHBJ production practices. WHBJ had

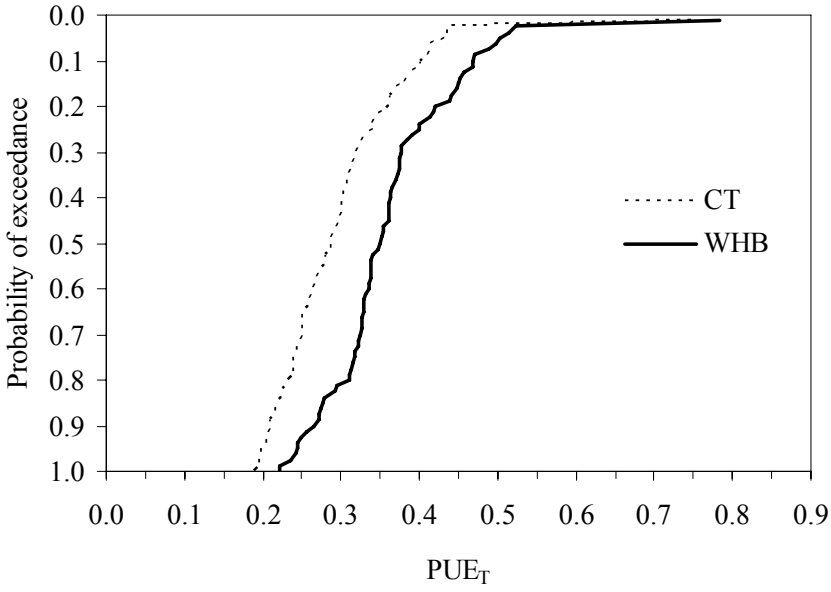

Figure 3

Cumulative probability functions of precipitation use efficiency $\left(P U E_{T}\right)$ over 80 seasons, for the conventional tillage (CT) and in-field rainwater harvesting (WHB) production techniques

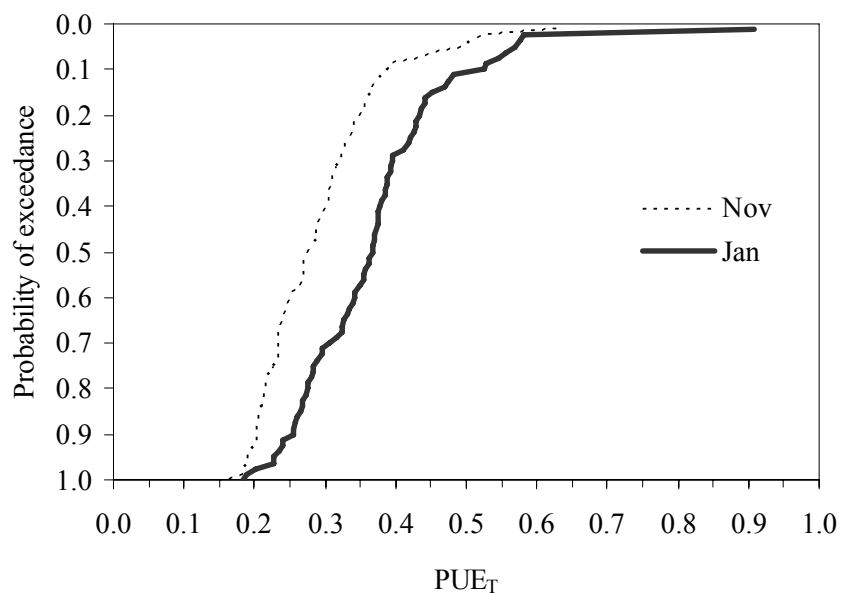

Figure 4

Cumulative probability functions of precipitation use efficiency $\left(P \cup E_{T}\right)$ over 80 seasons, for the November (Nov) and January (Jan) planting production techniques

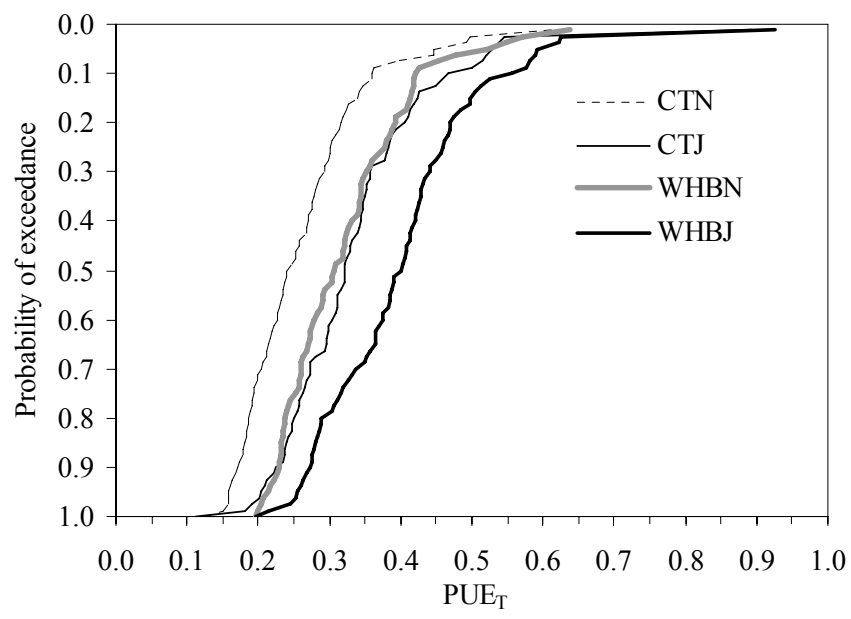

Figure 5

Cumulative probability functions of precipitation use efficiency $\left(P \cup E_{T}\right)$ over 80 seasons, for the November planting with conventional tillage (CTN), November planting with in-field rainwater harvesting (WHBN), January planting with conventional tillage (CTJ), and January planting with the in-field rainwater harvesting (WHBJ) production technique 


\begin{tabular}{|l|c|c|}
\hline \multicolumn{3}{|c|}{ TABLE 4 } \\
$\begin{array}{c}\text { Results of the Kolmogorov-Smirnov comparison } \\
\text { (Steel et al., 1997) of the grouped cumulative } \\
\text { probability functions (CPF) in Figures 2 and 3 }\end{array}$ \\
\hline CPF pair & D-statistic & Probability level \\
\hline CT vs. WHB & $0.4625^{*}$ & 0.000 \\
\hline Jan $v s$. Nov & $0.4000^{*}$ & 0.000 \\
\hline
\end{tabular}

* High significant difference

\begin{tabular}{|c|c|c|}
\hline \multicolumn{3}{|c|}{$\begin{array}{c}\text { TABLE } 5 \\
\text { Results of Kolmogorov-Smirnov comparison (Steel } \\
\text { et al., 1997) of the cumulative probability functions } \\
\text { (CPF) in Figure } 4\end{array}$} \\
\hline CPF pair & D-statistic & Probability level \\
\hline CTN vs. WHBN & $0.3250^{*}$ & 0.000 \\
\hline CTN vs. CTJ & $0.3750 *$ & 0.000 \\
\hline CTN vs. WHBJ & $0.5750^{*}$ & 0.000 \\
\hline WHBN vs. CTJ & $0.1250^{\mathrm{ns}}$ & 0.532 \\
\hline WHBN vs. WHBJ & $0.3875^{*}$ & 0.000 \\
\hline CTJ vs. WHBJ & $0.3750 *$ & 0.000 \\
\hline
\end{tabular}

the highest yield probability of all the production practices con-

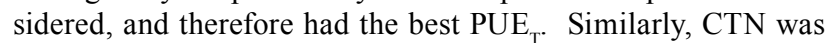
shown to have the worst PUE $_{\mathrm{T}}$. Although WHBN always had a higher yield probability than CTJ (Fig. 4), and was therefore considered to have a consistently better $\mathrm{PUE}_{\mathrm{T}}$, the probability lines were very close together and were therefore not significantly different (Table 5). It was concluded that the advantages associated with January planting using conventional tillage were matched by the disadvantages of November planting using infield rainwater harvesting.

\section{Conclusions}

Mean precipitation use efficiency ( $\mathrm{PUE}_{\mathrm{T}}$ ) was 0.260 for $\mathrm{CTN}$, 0.320 for WHBN, 0.334 for CTJ, and 0.400 for WHBJ, over the 80 seasons under consideration. The results demonstrated and quantified the advantage of in-field rainwater harvesting relative to conventional tillage, and January planting relative to November planting. Cumulative probability functions, based on estimated long-term yields, tested statistically using the Kolmogorov-Smirnov test, showed that $\mathrm{PUE}_{\mathrm{T}}$ for in-field rainwater harvesting was significantly better than $\mathrm{PUE}_{\mathrm{T}}$ for conventional tillage. It was similarly shown that $\mathrm{PUE}_{\mathrm{T}}$ for January planting was significantly better than $\mathrm{PUE}_{T}$ for November planting.

It was concluded that the higher $\mathrm{PUE}_{\mathrm{T}}$ of the in-field rainwater harvesting production practice compared to the conventional tillage production practice was probably due to very little runoff and reduced evaporation in the former. It was concluded that the higher $\mathrm{PUE}_{\mathrm{T}}$ for January planting relative to November planting was mainly due to the short growing season cultivar that flowered in March, the month with the most favourable climate.

Results presented here reflect the unique environmental conditions for the semi-arid Glen/Hutton-Ventersdorp ecotope, located at Glen and should therefore only be extrapolated to other study areas with caution.

\section{Acknowledgements}

Our sincere thanks to Ms. Linda De Wet for aiding in the computation of the vapour pressure deficit and Mr. Mike Fair for helping with the statistical analyses. Both are affiliated with the University of the Free State.

\section{References}

ALLEN RG, PEREIRA LS, RAES D and SMITH M (1998) Crop evapotranspiration: Guidelines for computing crop water requirements. FAO Irrigation and Drainage Paper 56. FAO, Rome.

BOTHA JJ, VAN RENSBURG LD, ANDERSON JJ, HENSLEY M, MACHELI MS, VAN STADEN PP, KUNDHLANDE G, GROENEWALD DG and BAIPHETHI MN (2003) Water Conservation Practices on Small Plots in Semi-Arid Areas to Enhance Rainfall Use Efficiency, Food Security, and Sustainable Crop Production. WRC Report No 1176/1/03. Water Research Commission, Pretoria.

BOTHA JJ (2006) Evaluation of Maize and Sunflower Production in a Semi-Arid Area using In-Field Rainwater Harvesting. Unpublished Ph.D. Thesis, University of the Free State, Bloemfontein.

GREGORY PJ (1989) Concepts of water use efficiency. Proc. of an Int. Workshop on Soil and Crop Management for Improved Water Use Efficiency in Rainfed Areas. May 1989, Turkey. ICARDA.

HATTINGH HW (1993) Die Beraming van Grondoppervlakverdamping by Droëlandkoring en -Mielieverbouing. Unpublished M.Sc. Thesis, University of the Free State, Bloemfontein.

HENSLEY M, BOTHA JJ, ANDERSON JJ, VAN STADEN PP and DU TOIT A (2000) Optimizing Rainfall Use Efficiency for Developing Farmers with Limited Access to Irrigation Water. WRC Report No. 878/1/00. Water Research Commission, Pretoria.

HENSLEY M, SNYMAN PJ and POTGIETER HLJ (1990) A parameter for describing the efficiency of water use in rain-fed cropping. Poster paper: Climatic risk in crop production: Models and management in the semi-arid tropics and sub-tropics. Proc. CSIRO Symposium. Brisbane, Australia. July 1990.

HILLEL D (1972) The field water balance and water use efficiency. In: Hillel D (ed.) Optimizing the Soil Physical Environment Towards Greater Crop Yields. Academic Press, London.

MACVICAR CN, SCOTNEY DM, SKINNER TE, NIEHAUS HS and LOUBSER JH (1974) A classification of land (climate, terrain form, soil) primarily for rain fed agriculture. S. Afr. J. Agric. Ext. 3 22-24.

SAWS (2005) Personal communication. South African Weather Service, Department of Environmental Affairs and Tourism, Bloemfontein.

SOIL CLASSIFICATION WORKING GROUP (1991) Soil classification - A taxonomic system for South Africa. Mem. Agric. Nat. Resour. S. Afr. No. 15. Department of Agricultural Development, Pretoria.

STEEL RGD, TORRIE JH and DICKEY DA (1997) Principles and Procedures of Statistics: A Biometrical Approach ( $3^{\text {rd }}$ edn.). MacGraw-Hill, New York.

TANNER CB and SINCLAIR TR (1983) Efficient water use in crop production: Research or re-search? In: Taylor HM and Jordan WR (eds.) Limitations to Efficient Water Use in Crop Production. Am. Soc. of Agron., Madison, Wis.

WALKER GK (1986) Transpiration efficiency of field grown maize. Field Crops Res. 14 29-39.

ZERE TB (2003) Evaluating Maize Production Potential of Selected Semi-arid Ecotopes Using a Water Balance Model. M.Sc. Agric. Dissertation, University of the Free State, Bloemfontein.

ZERE TB, VAN HUYSSTEEN CW and HENSLEY M (2005a) Development of a simple empirical model for predicting maize yields in a semi-arid area. S. Afr. J. Plant \& Soil 22 22-27.

ZERE TB, VAN HUYSSTEEN CW and HENSLEY M (2005b) Estimation of runoff at Glen in the Free State Province of South Africa. Water SA 31 (1) 17-21. 